\title{
Islamic Work Ethic Elements and Soldiers' Work Performance
}

\author{
Ahmad Azan Ridzuan and W. Norhasniah W. Husin \\ National Defense University of Malaysia \\ Sungai Besi Camp, 57000 Kuala Lumpur, Malaysia \\ azan@upnm.edu.my \\ hasni_wan02@yahoo.com
}

\author{
Wan Kamal Mujani \\ Department of Arabic Studies \& Islamic Civilization \\ Faculty of Islamic Studies \\ The National University of Malaysia, 43600 Bangi Malaysia \\ inawan@ukm.edu.my
}

\begin{abstract}
This study examines the correlation between Islamic Work Ethic (IWE) elements and work performance using self-administered questionnaires gathered from 326 samples of Army officers and other ranks. The quantitative research has been conducted on soldiers based at Sungai Besi Camp, Kuala Lumpur. The data's collected has been analyzed by using SmartPLS version 3.0 path model analysis resulted four important findings: first, Akhlaq was significantly associated with work performance. Second, leadership was significantly associated with work performance. Third, environment was significantly associated with work performance. Fourth, Syura was significantly associated with work performance. These results confirm that IWE elements are vital and act as important determinant of work performance in the studied organization. Further, this study will be thoroughly offer discussion, and conclusion.
\end{abstract}

Keywords-Islam; IWE; work ethic; leadership; army; Malaysia

\section{INTRODUCTION}

Ethics is the moral principle that individuals inject into their decision making process and that helps temper the last outcome to comfort to the norms of their society [1][2][3]. Johnson defines as the science of conduct, its represents an intellectual enterprise, a rational enquiry into its subject matter in the hope of gaining acquired knowledge [4]. Rizvi viewed that Islamic ethics is an integrated body of concepts about means and ends of human life as presented by total life, including administration [5]. IWE is originally based on Qur'an, the teachings of the Prophet who denoted that hard work caused sins to be absolved and the legacy of the four Caliphs of Islam [6], [7]. IWE would be defined as a set of ethical principles prescribing a behavioral code that explains what is good and right, bad and wrong, it may even outline moral duty and obligations [8]. In the Malaysian Armed Forces, the Religious Corps (Kor Agama Angkatan Tentera or KAGAT) was formed on 16 April 1985 to fulfill the need to enhance the spiritual strength in soldiers. The religious activities in the Army are to develop cohesion and sustaining the moral values of its soldiers.

\section{LITERATURE REVIEW}

According to Ajmain @ Jimain and Ab. Halim, Akhlaq refers to the behaviors which are internalized in the soul of a person and when good behaviors are executed it shows a person has performed good Akhlaq, and if the behaviors executed are bad behaviors it shows bad Akhlaq [9]. Ali proposed that leaders need to have good leadership qualities such as patience (Sabr), conviction (Yaqin), knowledge (Ilm), communication (Fatanah), enterprise (Iqdam) and leniency (Lin) in order to serve and guide their followers' performance to achieve organization goals [10]. Implementation of work environment through spiritual activities, good work cultures such as honesty, responsibility and highly discipline, and conducive physical facilities leads to the successful of JCorp management [11]. Syura (mutual consultation) refers to a collective mutual consultation and empowerment. Syura also refers to participative work force molded in the spirit of oneness to achieve performance. Wan Norhayate et al. mentioned performance implies an even extensive outlook to stimulate people for higher performance [12]. Abbasi defined performance as proficiency (Ihsan) which means doing good job or doing tasks in a proficient manner [13].

\section{RELATIONSHIP BETWEEN IWE ELEMENTS AND WORK PERFORMANCE}

A study by A. Shukor et al. on 341 students, who have taken the Islamic Education course at three Premier Polytechnic Students in Malaysia found that the correlation is positive, showing that the increase of Akhlaq self-regulation leads to an increase in academic performance [14]. A. H. Mat Tuah et al. mention the significance of Islamic Education in moulding the Akhlaq of the Muslim Malay students will be able to strengthen the spiritual values to cope with the new environment [15]. Study by Wan Norhayate on 11 Takaful operators and top management Islamic leaders in Malaysian Takaful industry licensed by Bank Negara Malaysia also found the attributes of Islamic leadership and Syura to the improvement of organizational performance. Besides, Muhammad Mustakim studied the work ethics practiced by the top management, officers and employees at JCorp by conducting semi structured interviews to 15 interviewees encompassing top management and executives of JCorp and the results showed that the JCorp management had employed environment strategies to increase work performance. This literature was used to develop the hypothesis for this study as follows:

Hypothesis 1: There is a positive relationship between Akhlaq and work performance. 
Hypothesis 2: There is a positive relationship between leadership and work performance.

Hypothesis 3: There is a positive relationship between environment and work performance.

Hypothesis 4: There is a positive relationship between Syura and work performance.

\section{MEthodOLOGY}

This study used a cross-sectional research design which allowed the researchers to integrate IWE elements literature, a pilot study and the actual survey to gather data for the study. The use of this data collection method reduces bias and ensures high-quality data [16], [17]. This study gathered data from the Headquarters' of Field Army, Headquarters' of Station Staff Sungai Besi, and the 1st Battalion of Royal Malay Regiment that based at Sungai Besi Camp, Kuala Lumpur. At the initial stage, a pilot study was conducted via a survey questionnaire with five experienced military officers who had been involved in the management of the units helped to develop the survey questionnaire for the actual research.

The survey questionnaires were developed from many validated scales such as Ali; 6 items of Akhlaq, 8 items of leadership, 7 items of work environment, 9 items of Syura and 11 items of work performance that were adapted from IWE literature and work performance scale. All these items were measured using a seven-point scale ranging. Demographic variables were used as the controlling variables. A convenient sampling technique was used to distribute the survey questionnaires. The participation of the soldiers was completely voluntary. A total of 326 usable questionnaires were returned to the researchers, yielding a $90 \%$ response rate. The SmartPLS version 3.0 was employed to analyze the survey questionnaires by testing the confirmatory factor analysis and test the research hypotheses [18].

\section{RESUlts}

In terms of sample profile, most respondents are male soldiers (89.6\%), rank of Corporal/Lance Corporal or equivalent $(51.5 \%)$, unit from 1st Battalion of Royal Malay Regiment (61.0\%), aged group from 21 to 30 years old (54.9\%), married status soldiers comprises (56.1\%), soldiers who served between 11 to 15 years (35.0\%), SPM/MCE/SPMV holders (70.9\%), soldiers salary between RM 2, 000-RM 3,500 a month (46.9\%), and mostly frequency attending organized religious activities more than 3 times a month (40.5\%).

The outcomes of confirmatory factor analysis were shown in Tables 1 and 2. Table 1 shows that IWE elements, and work performance had the values of average variance extracted (AVE) larger than 0.5, indicating that they met the acceptable standard of convergent validity [19]. The diagonal values of $\sqrt{ }$ AVE were greater than the squared correlation with other constructs in off diagonal, showing that all constructs met the acceptable standard of discriminant validity.
TABLE I. THE RESUlTS OF CONVERGENT AND DISCRIMINANT VALIDITY ANALYSIS

\begin{tabular}{|c|c|c|c|c|c|c|}
\hline & AVE & Akhlaq & Leadership & Environment & Performance & Syura \\
\hline Akhlaq & 0.726 & 0.852 & & & & \\
\hline Leadership & 0.588 & 0.592 & 0.767 & & & \\
\hline Environment & 0.712 & 0.709 & 0.679 & 0.844 & & \\
\hline Performance & 0.759 & 0.694 & 0.728 & 0.784 & 0.871 & \\
\hline Syura & 0.725 & 0.680 & 0.753 & 0.812 & 0.797 & 0.852 \\
\hline
\end{tabular}

Table 2 shows all constructs loaded exceeding the specified minimum, 0.7 , showing that the validity of measurement model met the criteria. The composite reliability and Cronbach's Alpha had values greater than 0.8, indicating that the instrument used maintained high internal consistency.

TABLE II. THE RESUlTS OF CROSS LOADINGS FOR DIFFERENT CONSTRUCTS AND CONSTRUCT RELIABILITY ANALYSIS

\begin{tabular}{|c|c|c|c|c|}
\hline Construct & $\begin{array}{c}\text { Number } \\
\text { of Item }\end{array}$ & $\begin{array}{c}\text { Cross Factor } \\
\text { Loadings }\end{array}$ & $\begin{array}{c}\text { Composite } \\
\text { Reliability }\end{array}$ & $\begin{array}{c}\text { Cronbach } \\
\text { Alpha }\end{array}$ \\
\hline Akhlaq & 6 & $0.765-0.896$ & 0.941 & 0.924 \\
\hline Leadership & 12 & $0.726-0.810$ & 0.945 & 0.936 \\
\hline Environment & 7 & $0.763-0.893$ & 0.945 & 0.932 \\
\hline Performance & 6 & $0.858-0.892$ & 0.950 & 0.936 \\
\hline Syura & 8 & $0.824-0.883$ & 0.955 & 0.946 \\
\hline
\end{tabular}

Table 3 shows the outcomes of testing SmartPLS path model. The value of R2 is used as an indicator of the overall predictive strength of the model. In this model testing, the inclusion of Akhlaq, Leadership, Environment, and Syura in the analysis had explained 72.7 percent of the variance in work performance. The results of SmartPLS path model analysis revealed four important findings as shown in table 3 . All of the hypothesis H1, H2, H3, and H4 are significantly correlated, therefore all are supported. In overall, this result demonstrates that IWE elements are an important determinant of work performance in the studied organization.

TABLE III. OUtcomes OF TESTING SMARTPLS PATH MODEL

\begin{tabular}{|l|c|c|c|c|c|}
\hline Relationship & $\boldsymbol{\beta}$ & $\begin{array}{c}\mathbf{t} \\
\text { value }\end{array}$ & $\begin{array}{c}\mathbf{p} \\
\text { value }\end{array}$ & $\mathbf{R}^{2}$ & Result \\
\cline { 1 - 4 } $\begin{array}{l}\text { H1 Akhlaq } \rightarrow \\
\text { Performance }\end{array}$ & 0.168 & 3.449 & 0.001 & & Significant \\
\cline { 1 - 4 } $\begin{array}{l}\text { H2 Leadership } \rightarrow \\
\text { Performance }\end{array}$ & 0.220 & 4.265 & 0.000 & \multirow{2}{*}{0.727} & Significant \\
\cline { 1 - 3 } $\begin{array}{l}\text { H3 Environment } \rightarrow \\
\text { Performance }\end{array}$ & 0.280 & 3.894 & 0.000 & Significant \\
\cline { 1 - 3 } $\begin{array}{l}\text { H4 Syura } \rightarrow \\
\text { Performance }\end{array}$ & 0.290 & 3.494 & 0.001 & & Significant \\
\hline
\end{tabular}

Significant at $* t \geq 1.96$

\section{SUMMARY}

The findings of this study had confirmed that IWE practices in studied organization do act as an important determinant of soldiers work performance. In the context of this study, well exposed soldiers with religious activities in the unit contribute to better work performance. According to the majority of the respondents, the levels of Akhlaq, Leadership, Environment, Syura, and Work Performance are substantial. This situation 
posits that majority of respondents feel that proper plan on religious program will increase soldiers interest on IWE and enhance work performance. Most of the officers believed that negative influence from outside become load of work they handle each day, the pattern of work and its design, as well as the work environment. With proper religious program are given more attention, its may help the unit to manage their soldiers at both individual and group levels to enhance work performance. As a result, the units need to put IWE elements into practice as it ensures the ultimate and the continuous success of the unit.

\section{ACKNOWLEDGMENT}

This research was financially supported by Ministry of Higher Education (Malaysia) and The National University of Malaysia (Grant No. RACE-2015/2017-001).

\section{REFERENCES}

[1] D. A. Morf. “A survey of ethics officers in large organizations,” Journal of Business Ethics, vol.20, 1999, pp. 265-271.

[2] E. A. Jamsari, W. K. Mujani, N. I. Ya'akub et al., The basis of leadership in Islam, Advances in Natural and Applied Sciences, vol.6(8), pp. 1399-1404, 2012.

[3] A. M. Ismail, W. K. Mujani, W. M. H. W. Hussain, \& N. I. Ya'akub, "The missing of moral entity in modern civilization: values and social aspects,” Advances in Natural and Applied Sciences, 6(6), pp. 985-994, 2012.

[4] O. A. Johnson, Ethics Selection from Classical and Contemporary Writers, New York: Holt, Rinehart and Winston, 1984.

[5] A. Rizvi, "Harmonizing bureaucracy with Islamic ideology: a behavioral approach,” Pakistan Journal of Public Administration, vol.XXI, p.14, 1985.

[6] A. Ali, "Scaling an Islamic work ethics," The Journal of Social Psychology, vol.128 (5), pp. 575-83, 2001.

[7] R.R. Rizk, "Back to basics: an Islamic perspective on business and work ethics,” Social Responsibility Journal, vol.1(2), pp. 246-254, 2008.
[8] R. Beekun, Islamic Business Ethics, Virginia: IIIT, 1997.

[9] Ajmain@Jimain Safar \& A. H. Tamuri, Penghayatan adab dan akhlak diri dalam kalangan pelajar sekolah menurut rakan sebaya (Manners and morals among students based on the evaluation of peers), Prosiding Seminar Antarabangsa Perguruan \& Pendidikan Islam (Proceeding of the International Seminar on Teachers and Islamic Education), Le Grandeur Hotel, Johor Darul Takzim, pp. 357-368, 2012.

[10] A. J. Ali, “Islamic perspectives on leadership: a model,” International Journal of Islamic and Middle Eastern Finance and Management, vol.2(2), pp. 160-180, 2009.

[11] M. M. Mohamed Noh et al., "Strategi dan faktor mempengaruhi perlaksanaan etika kerja Islam (EKI): kajian kes di JCorp (Strategies and factors affecting the implementation of Islamic work ethic: study case in JCorp,” GJAT, vol.4(1), pp. 97-111, 2014.

[12] W. N. Wan Daud et al., "Quality of Islamic leadership and organizational performance within the takaful industry in Malaysia: a conceptual study,” Asian Social Science, vol.10(21), pp.135-144, 2014.

[13] A. S. Abbasi, Role of Islamic leadership in value based corporate management, Ph.D. thesis, Islamabad, National University of Modern Language, 2008.

[14] K. A. Shukor, et al., Akhlaq self-regulation and students' performance in the islamic education course among premier polytechnic students in Malaysia, Proceeding of the First Seminar on Islamic Education and Research [SePPIM13]). Johore: Faculty of Islamic Civilization, pp.502521, 2013.

[15] A. H. Mat Tuah, “Memperkasakan jati diri melayu-muslim menerusi pendidikan Islam dalam pengajaran akhlak (Empowering Malay-Muslim identity through Islamic education in teaching morals),” Jurnal Hadhari, Special Edition, pp.23-35, 2012.

[16] J.W. Creswell, Educational Research: Planning, Conduct and Evaluating Quantitative and Qualitative Research. Boston: Pearson Education, 2012.

[17] U. Sekaran \& R. Bougie, Research Methods for Business: A Skill Building Approach, United Kingdom: John Wiley \& Sons Ltd, 2013.

[18] J. Henseler et al., "The use of partial least squares path modeling in international marketing," Advances in International Marketing, pp.277320, 2009.

[19] C. Fornell \& D.F. Larcker, "Evaluating structural equation models with unobservable variables and measurement error,” Journal of Marketing Research, vol.XVIII, pp.39-50, 1981. 